\author{
ANNA MIECHÓWKA ${ }^{1 *}$, MAREK DREWNIK ${ }^{2}$ \\ ${ }^{1}$ University of Agriculture in Krakow, Faculty of Agriculture and Economics, Institute of Soil Science and Agrophysics, \\ Department of Soil Science and Soil Protection, Al. Mickiewicza 21, 31-120 Kraków, Poland \\ 2 Jagiellonian University, Institute of Geography and Spatial Management, Department of Pedology and Soil Geography \\ ul. Gronostajowa 7, 30-387 Kraków, Poland
}

\title{
Rendzina soils in the Tatra Mountains, central Europe: a review
}

\begin{abstract}
The article presents the overview of the rendzinas found in the Polish Tatra mountains based on literature data and unpublished authors results and observations. Particular attention was paid to soil properties related to the high mountain environment in Poland occurring only in the the Tatra Mountains. The influence of soil forming factors on the genesis of rendzinas and their spatial distribution was described. Furthermore the soils properties were analysed in order of distinguished soil units. Finally the proposal for classification of Tatra rendzinas was given.
\end{abstract}

Key words: Rendzinas, mountain soils, Tatra Mts., humus forms

\section{INTRODUCTION}

Tatra Mountains (Tatra) are located in the northwestern part of the Carpathian Chain on the border between Slovakia and Poland. These are the highest mountains of the Carpathians in this part of Europe (Gerlach, $2655 \mathrm{~m}$ a.s.1.). The geological structure of this area is very diverse (Passendorfer 1996). There is a well-developed vertical geoecological zonality (lower and upper montane belt, sub-Alpine and Alpine zone, bare rocky belt) (Kotarba 1996) and a post-glacial relief (Klimaszewski 1996). Due to high natural values and cultural heritage, this area is protected by national parks both on the Polish and on the Slovak side of the border. Those parks had been jointly entered in the World Network of Biosphere Reserves (UNESCO).

Rendzina soil (rendzinas) are a very important component of the Tatra ecosystems. These soils develop from carbonate rocks and occur in all regions of the Tatra Mountains (Skiba et al. 2015). They predominate in the soil cover of the Regiel Tatra region (subregions: Orawicko-Witowskie Tatra, Kościeliskie Tatra, Zakopiańskie Tatra, Kopy Sołtysie group, Jaworzyńskie Tatra) (regional subdivision of the Tatra Mts. by Balon et al. 2015 is implemented) and in the Belianske Tatra region (Fig. 1). In the Western Tatra region, rendzinas are predominant soils in the Siwy Wierch group, in the Czerwone Wierchy massif (including Giewont Mt.) and in the

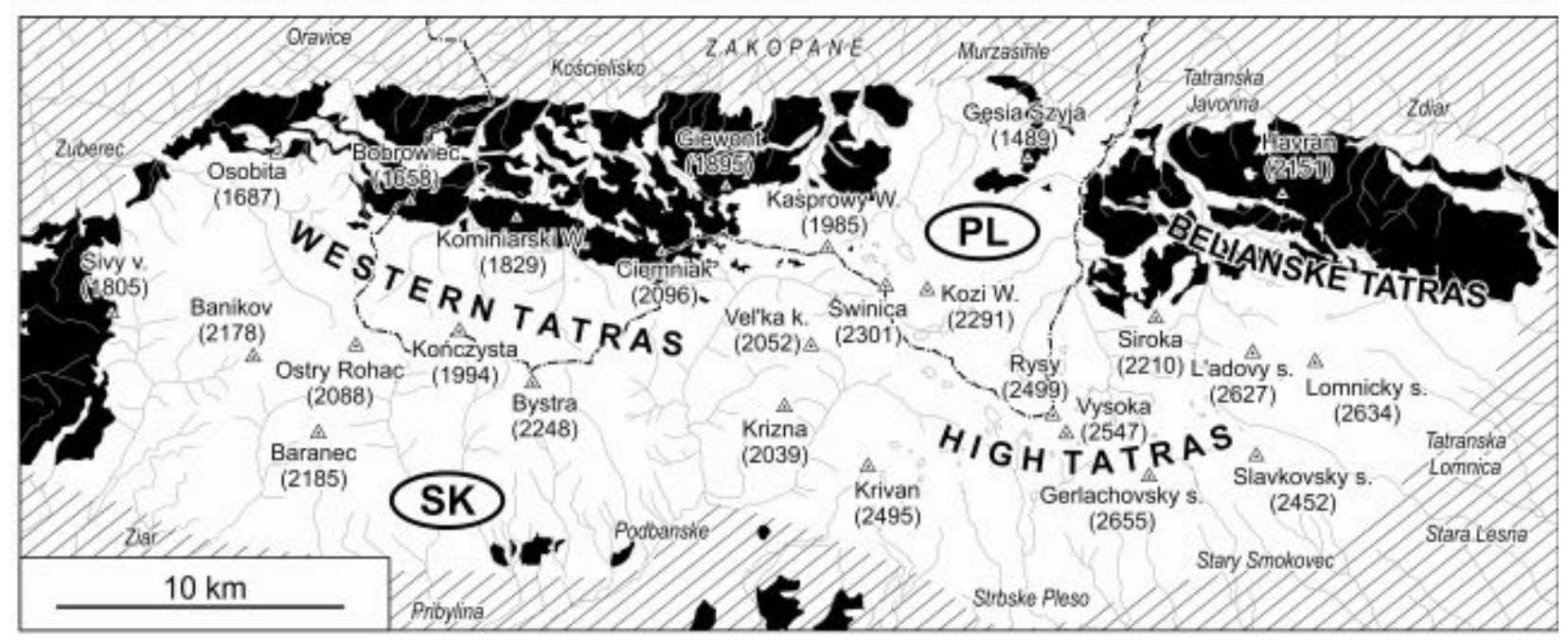

FIGURE 1. Spatial distribution of rendzinas (black coloured contours) in the Tatra Mountains 
Kominiarski Wierch massif. They also occur in the Osobita-Bobrowiec group (both in the eastern and western part). Rendzinas can also be found in Rohače area (Studeny Potok valley) and in the Tomanowo-Jamnickie Wierchy group. In the High Tatra region, these soils are found on a much smaller area - on the northern mountain slopes of Szeroka Jaworzyńska massif, in the north-western part of the Jaworowy-Kieżmarski massif and in the northern mountain slopes of the Waksmundzki massif. In the whole Tatra, rendzinas occupy $\sim 20 \%$ of the area (Fig. 1). In the (Polish) Tatra National Park rendzinas occupy about $35 \%$ of the soil cover (Skiba 2002).

Rendzinas create natural habitats (mostly protected in the European Union: Habitat Directive, Annex 1) important for the protection of biodiversity in the Tatra. They determine the occurrence of many valuable species of plants and animals (Dyduch-Falniowska 1991, Miechówka and Piękoś-Mirkowa 1998, PiękośMirkowa et al. 2001). 31 endemic species of vascular plants occurring in the Polish part of the Tatra can be found on the rendzinas (of 35 in total), 12 of them growing almost exclusively (over $90 \%$ of sites) or exclusively on these soils (Piękoś-Mirkowa et al. 1996).

The importance of rendzinas to the natural environment was the cause of the researchers' particular interest in these soils, both on the Polish and Slovakian part of the Tatra Mountains. Rendzinas of the Polish Tatra have been examined in detail during large-scale soil survey works in the 1970s and 1980s (Komornicki et al. 1975, Komornicki 1977, Komornicki et al. 1984a, 1984b) and described both in the monographs of the Tatra National Park (Strzemski 1956, Adamczyk 1962a, Komornicki and Skiba 1996) and entire Tatra Mountains (Koreň et al. 2010). Finally the spatial distribution of rendzinas in the Tatra in different scales has been shown in the maps (Strzemski 1956, Komornicki et al. 1975, Komornicki 1977, Komornicki et al. 1984a,1984b, Komornicki and Skiba 1985, Skiba 1999, Skiba et al. 2015).

Detailed scientific studies were carried out on the following topics concerning Tatra rendzinas: the influence of climate on the soil properties and the tendency of vertical soil zonality (Skiba 1983, 1985), the soil geochemistry (Oleksynowa et al. 1977, Miechówka 1989, 1990, 2001), both the properties and forms of humus (Niemyska-Łukaszuk 1977a, Niemyska-Łukaszuk and Miechówka 1996, Miechówka and Ciarkowska 1998, Miechówka 2000, Wasak and Drewnik 2012a, 2012b, 2015, Wasak 2013, 2014) and biological activity of soil (Drewnik 1998, 2006, Miechówka 2000, Miechówka and Ciarkowska 2002, Ciarkowska and Miechówka 2005a, 2005b, Wasak 2014), as well as the concentration of heavy metals in soil (Miechówka 2000, Niemyska-Łukaszuk et al. 2000, Niemyska-Łukaszuk and Miechówka 2002, Miechówka et al. 2002, Miechówka and Niemyska-Łukaszuk 2004), the concentration of radionuclides in soil (Kubica et al. 2002, 2007, 2010) and their classification (Strzemski 1956, Adamczyk 1962b, Komornicki et al. 1975, Komornicki 1977, Skiba 1983, Komornicki et al. 1984a, 1984b, Komornicki and Skiba 1996, Miechówka 2000). In some of the above-mentioned works the micromorphological investigations were used (Niemyska--ukaszuk 1977b, Miechówka 2000, Ciarkowska and Miechówka 2005a, Drewnik 2006).

Rendzinas in the Slovakian part of the Tatra were described in monographic studies (Tarábek 1956, Midriak 1971, Pelišek 1973, Koreň 1994, Koreň et al. 1994, Bedrna and Račko 1999). A detailed scientific study, concerning mainly the rendzinas of the Belianske Tatra region, has been carried out on the following topics: the dynamics of the natural and human induces morphogenetic processes affecting the soil cover (Midriak 1983, Barančok and Varšavová 1996, Hreško et al. 2008), chemical properties of soils (Varšavová et al. 1999, Mišovičová 2003) and the problem of their pollution (Barančoková et al. 2009).

The aim of this work was to create an overview of characteristics the rendzinas found in the Polish Tatra mountains, based on literature data and unpublished authors results and observations. Particular attention was paid to soil properties related to the high mountain environment in Poland occurring only in the Tatra Mountains.

\section{Factors affecting the diversity of rendzinas}

The rendzinas in Tatra are very heterogeneous soils with respect to the morphological, physical, chemical, physicochemical and biological properties due to the diversity of the parent material, climatic conditions and plant cover in this area.

The carbonate rocks of the Wierchowa and Reglowa series (i.e. structural geological series distinguished in Tatra) are the parent material of the Tatra rendzinas. They are mainly: Triassic limestones and dolomites, Jurassic limestones and marls. There are also Eocene limestones on the border of the Tatra Mts. and Zakopane Basin. The carbonate rocks of the Tatra Mountains differ in their physical and chemical properties, thus their susceptibility to weathering is diverse. They form regolith of varying thickness, varying content of rock fragments, varying textures and chemical composition.

The thickness of regolith is related to the impact of both past and contemporary geomorphological 
processes. Present-day morphogenetic processes have the strongest effect on the soil cover diversity above the upper timberline (Skiba 2006). A specific kind of the soil cover variety called 'openwork soil cover' (so-called 'soil cover fragmentation') can be found in the Tatra (Strzemski 1956, Skiba 2006), which means the occurrence of the complex of well-formed rendzinas soils next to initial soils and next to soilless areas.

The parent material of the Tatra rendzinas is often a mixture of weathered parts of different rocks. For example the upper parts of the talus cone and talus slope in many cases consist of a mixture of carbonate rocks (limestones, dolomites and marls) and non-carbonate rocks (schists, quartzites). Similarly, the majority of rendzinas occuring on the mountain slopes contain some fine-earth admixtures originating from silicate rocks weathering. In fact, Tatra redzinas often develop on slope covers consisting of a mixture of different rocks occurring in the upper part of the slope. Rendzinas on the mountain slopes of Czerwone Wierchy massif are one such case (Miechówka 1998, Drewnik 2008). The huge admixture of granite gravel and fine earths in these soils coming from the 'crystalline cap' located in the top parts of the massif. A very heterogeneous geological material can also be found in soils occurring in many Tatra glades. For example in the border part of glade in the Kościeliska Valley a specific 'mélange' mixture of carbonate and non-carbonate debris of fluvioglacial origin can be found (Miechówka 1994). Finally, it should be noted that admixtures of aeolian-derived silt and clay coming from the weathering of various non-carbonate rocks (including granitoides) are often found in rendzinas. It can be assumed that most soils of the calcareous part of the Tatra originate from non-homogeneous parent material.

As the elevation increases, the mean annual temperature decreases (MAT from $\sim+6^{\circ} \mathrm{C}$ to $\sim-4^{\circ} \mathrm{C}$ ), the mean annual precipitation increases (MAP from $\sim 1200 \mathrm{~mm}$ to $\sim 1900 \mathrm{~mm}$ at ca. $2000 \mathrm{~m}$ a.s.1.) and the snow cover period becomes longer in Tatra. There are 5 climatic vertical zones: moderately cool, cool, very cool, moderately cold and cold (Hess 1996). The higher the soils are, the impact of climate on their formation is higher (Strzemski 1956, Adamczyk 1962a, Skiba 1983). Lower temperature and higher precipitation favour the accumulation of organic matter in soils in higher elevations (Skiba 1983, Drewnik 2006). There is also a greater leaching of basic cations from soils and thus their acidification is stronger (Miechówka and Głąb 1998). The climatogenic character of the Tatra rendzinas is expressed in their zonality. This phenomenon in Polish Tatra was described by Skiba (1983), after examining the soils of the northern mountain slope of Kominiarski massif. It is not always possible to notice the altitude zonality of rendzinas in each locations due to the relief, the differences in intensity of morphogenetic processes and unequal microclimatic conditions. It should be noticed that slope exposure also shapes the properties of rendzinas (Adamczyk 1962a).

Vegetation is an important factor affecting the morphology and properties of Tatra rendzinas. The plants in the montane belt and in the subalpine zone (trees and dwarf-pines respectively) influence the stability of the rendzinas. The root systems and low-lying branches mechanically protect soils against water erosion, creep and landslide, therefore soils are less exposed to the influence of morphogenetic processes in these areas (Adamczyk 1962b, Fabianowski 1962, Miechówka 2002). In forest ecosystems, both the species and the age of trees determine the quantity and quality of the accumulating litter, which affects the formation of different forms of soil humus in rendzinas (Wasak and Drewnik 2012a, Wasak 2013, 2014). In non-forest plant communities, vegetation may also have an impact on the diversity of humus forms, for example, there are much thicker organic $\mathrm{O}$ horizons in rendzinas under bilberry shrubs than under grasslands in the Tatra glades (Miechówka and Ciarkowska 1998, Miechówka 2000).

\section{Humus forms}

All morphological and functional types of humus forms common in calcareous soils described in the European Humus Forms Reference Base (Jabiol et al. 2013) have been found in the Tatra mountains: mull, amphi and tangel types and most of their subtypes. The variety of humus forms present in the rendzinas causes a tendency to treat them, together with depth and the content of stones in the soil body, as the main classification factor due to their diagnostic and habitat functions.

The humus form tangel (Kubiena 1953) is common in the rendzinas occurring in the upper montane natural spruce forest and in the rendzinas occurring in the Alpine and sub-Alpine zone under dwarf-pine shrubs, under bilberry shrubs (subtype: dystangel) and under calcareous grasslands (subtype: eutangel). This humus type is characterized, among others, by the sequence: a well-developed organic $\mathrm{O}$ horizons over humus A horizon with thickness no more than of half the O horizon.

Pachyamphi humus form can be found in rendzinas both under the artificial spruce monoculture in the lower montane belt (Wasak 2014), under the 
calcareous grasslands and under dwarf-pine shrubs (Miechówka 2002). In these soils, organic O horizon consists of well-humified organic material (OH horizon). The sequence of humus horizons is completed by a biomezostructural A horizon with a thickness of more than half of the OH-horizon thickness. It is assumed that amphi humus form is typical for the Mediterranean soil (Zanella et al. 2011), but it has already been described as occurring in soils of Alps (Graefe 2007).

The humus mull form occur in rendzinas at different elevations and under different vegetation (beech forests, calcareous grasslands, dwarf-pine shrubs) (Miechówka 2000, 2002, Wasak 2013). An extremely high content of soil organic carbon (SOC) in mull humus type is specific to Tatra rendzinas.

In previous works concerning the type of humus in the Tatra rendzinas, classifications of humus other than the European Humus Forms Reference Base (Jabiol et al. 2013) commonly were used: according to the Polish Soil Classification (Niemyska--ukaszuk 1977a), according to Kubiena (1953) (Miechówka 2000) and according to INRA (1992) (Miechówka 2002). Humus forms in Tatra rendzinas are quite similar to those described by Kubiena (1970) in the Alps (Miechówka and Ciarkowska 1998, Miechówka 2000). Their names were and so far are used in creation of subtypes of rendzinas. An example may be the name ,tangelrendzina” used by Skiba (1983) and used also in Slovakia, or the name ,rendzina smolista" used by Miechówka (2000), and used for the first time by Tarábek (1956) and then often used by other Slovak soil scientists (Linkeš 1981).

\section{Classification of Tatra rendzinas}

The proposal for Tatra rendzinas classification is given in Table 1. Changes as compared to the Polish soil classification (Systematyka gleb Polski 2011) have been done taking into account the specificity of the Tatra rendzinas (especially the impact on the habitats). The translation of Polish soil names into English according to Świtoniak et al. (2016) was done with some changes.

Soils having thickness of less than $40 \mathrm{~cm}$ to solid carbonate rock (limestone, dolomite, marl) or soils containing to this depth at least $15 \%$ carbonate rock fragments should be classified as rendzinas. Despite carbonate rock under solum and/or significant percentage of the carbonate rock fragments in soil body, also rendzinas which do not contain calcaric or dolomitic material can be found in Tatra. For better characterization, raw-humus rendzinas were divided regarding humus forms in these soils.

\section{Soil description}

Raw rocky rendzinas (Rędziny inicjalne skaliste)

Raw rocky rendzinas are found in all geoecological zones and belts in the Tatra (lower and upper montane belt, sub-Alpine and Alpine zone, bare rocky belt). These soils are typical for crevices, gaps and ledges in the rocky wall and rocky slopes on outcrops and rocks composed of limestones, dolomites and marls.

Raw rocky rendzinas occurring in crevices and gaps in the rock have specific characteristics due to the fact that they are surrounded by a solid rock at least on two sides. The properties of the soil material

TABLE 1. Key to the Tatra rendzinas classification

Soils having thickness $\leq 40 \mathrm{~cm}$ to solid carbonate rock (limestone, dolomite, marl) or soils containing to this depth at least $15 \%$ carbonate rock fragments

\begin{tabular}{|c|c|c|c|}
\hline [1] & & having continuous carbonate rock starting $\leq 10 \mathrm{~cm}$ & $\rightarrow$ Raw rocky rendzina \\
\hline [2] & & $\begin{array}{l}\text { having } \geq 80 \% \text { (by volume) coarse fragments of carbonate rock to a depth } \\
\text { of } 40 \mathrm{~cm} \text { AND combined thickness of } \mathrm{O}+\mathrm{A}+\mathrm{AC} \text { horizons } \leq 10 \mathrm{~cm}\end{array}$ & $\rightarrow$ Raw debris rendzina \\
\hline [3] & $\begin{array}{l}{[3 a]} \\
{[3 b]}\end{array}$ & $\begin{array}{l}\text { having folic*horizon (thickness of } \geq 10 \mathrm{~cm} \text { and }<40 \mathrm{~cm} \text { ) } \\
\text { over A or AC horizon } \\
\text { having tangel humus form } * * \\
\text { having amphi humus form } * *\end{array}$ & $\begin{aligned} \rightarrow \text { Raw-humus rendzina } & \\
& \quad \text { Subtypes: } \\
& \rightarrow \text { Tangel-rendzina } \\
& \rightarrow \text { Amphi-rendzina }\end{aligned}$ \\
\hline [4] & \multicolumn{2}{|c|}{ having mollic* horizon } & $\rightarrow$ Humus rendzina \\
\hline [5] & \multicolumn{2}{|c|}{ having cambic* horizon } & $\rightarrow$ Brown rendzina \\
\hline \multirow[t]{2}{*}{$\overline{[6]}$} & (others) & & $\rightarrow$ Proper rendzina \\
\hline & $\begin{array}{l}6 a] \\
{[6 b]}\end{array}$ & $\begin{array}{l}\text { having } \geq 80 \% \text { (by volume) coarse fragments of carbonate rock to } \\
\text { a depth of } 40 \mathrm{~cm} \\
\text { (others) }\end{array}$ & $\begin{array}{l}\rightarrow \text { Debris proper rendzina } \\
\rightarrow \text { Typical proper rendzina }\end{array}$ \\
\hline
\end{tabular}

* sensu IUSS Working Group WRB 2015; ** sensu Jabiol et al. 2013. 
building these soils depend mainly on the moisture conditions and the size of the gaps. Above upper timberline raw rocky rendzinas are usually very moist or even wet (in many cases water flows through it). Within montane belt, the soil moisture depends on the exposure of the rock wall (or slope). The soils of the northern exposure rock walls are usually very moist or wet, whereas the soil of the southern exposure walls are usually only slightly moist. The content of soil organic carbon (SOC) and carbonates $\left(\mathrm{eqCaCO}_{3}\right)$ in those soils is closely linked to moisture conditions (Table 2). In the raw rocky rendzinas found in higher elevations, above upper timberline (profiles 1-3) (Table 2) the SOC concentration is usually $>12 \%$, whereas the carbonate concentration is usually $<5 \%$. The reaction class of these soils is slightly acidic or acidic ( $\mathrm{pH}$ in water 5.2-6.7). Raw rocky rendzinas occurring in lower elevations, within montane belt, are more diverse in terms of SOC and carbonate content, and they are characterized by a neutral or slightly alkaline reaction $(\mathrm{pH}$ in water $6.6-7.8)$ (profiles 4 and 5) (Table 2).

Raw rocky rendzinas as described above create habitats for plant communities specific for rocky gaps (e.g. Drabo-Artemisietum petrosae, Asplenio viridisCystopteridetum, Asplenitum rutae murariae-trichomanis) and for plant communities typical for calcareous grasslands (Festuco versicoloris-Seslerietum tatrae, Carici-Festucetum tatrae). Raw rocky rendzinas occurring in crevices and gaps are relatively poorly investigated due to difficulties in obtaining research material (narrow gaps) and due to legal restrictions (protection of habitats and plant species).

TABLE 2. Basic properties of raw rocky rendzinas

\begin{tabular}{|c|c|c|c|c|c|c|c|c|}
\hline \multirow[t]{2}{*}{ Horizon } & Thickness & $>2 \mathrm{~mm}$ & $\mathrm{pH}$ & $\mathrm{pH}$ & $\mathrm{SOC}$ & \multirow[t]{2}{*}{$\mathrm{C} / \mathrm{N}$} & $\mathrm{eqCaCO}_{3} \quad \mathrm{BS}$ & \multirow{2}{*}{$\begin{array}{l}\text { Reference / } \\
\text { Remarks }\end{array}$} \\
\hline & $\mathrm{cm}$ & $\% \mathrm{v} / \mathrm{v}$ & $\left(\mathrm{H}_{2} \mathrm{O}\right)$ & $(\mathrm{KCl})$ & $\%$ & & $\%$ & \\
\hline \multicolumn{8}{|c|}{$\begin{array}{l}\text { 1. Stoły, } 1,920 \mathrm{~m} \text { a.s.l., crevice within rock wall } 60^{\circ} \mathrm{S} \text {, Festuco versicoloris-Seslerietum tatrae, } \\
\text { Somerirendzic Nudillithic LEPTOSOL (Hyperhumic) }\end{array}$} & \multirow[t]{2}{*}{$\begin{array}{l}\text { Piękoś-Mirkowa } \\
\text { et al. (2001) }\end{array}$} \\
\hline $\mathrm{A}$ & $0-10$ & 0 & 6.2 & 5.6 & 13.99 & 17.7 & $0.55 \quad 90.6$ & \\
\hline \multicolumn{8}{|c|}{$\begin{array}{l}\text { 2. Stoły, } 1,900 \mathrm{~m} \text { a.s.l., crevice within rock wall } 45^{\circ} \mathrm{SWW} \text {, Festuco versicoloris-Seslerietum tatrae, } \\
\text { Eutric Nudilithic LEPTOSOL }\end{array}$} & $\begin{array}{l}\text { Piękoś-Mirkowa } \\
\text { et al. (2001) }\end{array}$ \\
\hline $\mathrm{O}$ & $0-9$ & 0 & 5.3 & 4.8 & 23.85 & 13.7 & $0.27 \quad$ n.d. & / very moist \\
\hline \multicolumn{8}{|c|}{$\begin{array}{l}\text { 3. Długi Giewont, } 1,650 \mathrm{~m} \text { a.s.l., rock wall } 80^{\circ} \mathrm{N} \text {, Carici-Festucetum tatrae, } \\
\text { Hypereutric Nudilithic LEPTOSOL }\end{array}$} & (unpublished) \\
\hline OC & $0-5$ & 0 & 6.7 & 6.4 & 24.50 & 14.5 & 93.4 & / very moist \\
\hline
\end{tabular}

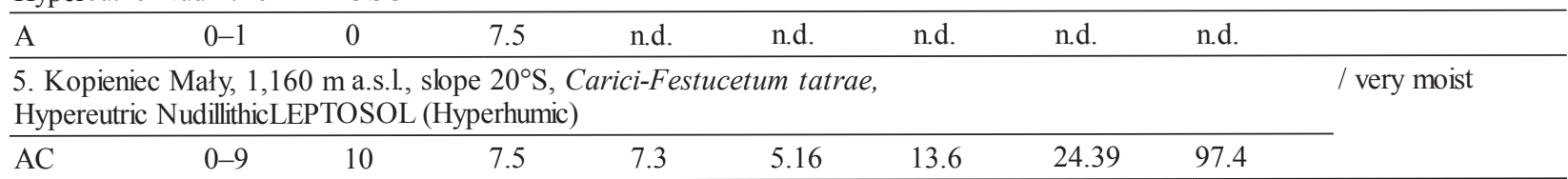

6. Ciemniak, 2,025 $\mathrm{m}$ a.s.l., slope $5^{\circ} \mathrm{NW}$, calcareous alpine grasslands with calcifuge species, (unpublished) Dystric Hypersekeletic Lithic LEPTOSOL (Hyperhumic)

\begin{tabular}{lllllllll}
\hline $\mathrm{AC}$ & $2-10$ & 80 & 5.7 & 5.2 & 5.47 & 11.6 & 0.64 & 41.4 \\
\hline
\end{tabular}

7. Kopa Kondracka, $1,257 \mathrm{~m}$ a.s.l., rock slope $75^{\circ} \mathrm{NEE}$, Seslerietalia variae with calcifuge species, Eutric Skeletic Lithic LEPTOSOL (Humic)

\begin{tabular}{lllllllll}
\hline $\mathrm{AC}$ & 10 & 50 & 5.9 & 5.2 & 1.32 & 9.4 & 0.73 & 66.3
\end{tabular} (unpublished)

8. Kobylarz, 1,820 $\mathrm{m}$ a.s.l., rock slope $50^{\circ} \mathrm{NNW}$, Festuco versicoloris-Seslerietum tatrae, (unpublished) Lithic Calcaric LEPTOSOL (Hyperhumic)

\begin{tabular}{lllllllll}
\hline A & $2-10$ & 5 & 6.7 & 6.1 & 19.57 & 15.5 & 4.93 & 81.2
\end{tabular}

9. Stoły, $1,730 \mathrm{~m}$ a.s.l., ledge within rock wall $30^{\circ} \mathrm{N}$, Carici-Festucetum tatrae, Hyperskeletic Lithic Calcaric LEPTOSOL (Hyperhumic)

\begin{tabular}{lrrrrrrrr}
\hline AC & $0-5$ & 80 & 7.2 & 6.9 & 8.93 & 11.2 & 60.07 & 97.9
\end{tabular}

10. Przednia Kopka, $1,055 \mathrm{~m}$ a.s.l., summit part $25^{\circ} \mathrm{NE}$, Carici-Festucetum tatrae, Lithic Calcaric LEPTOSOL (Hyperhumic

\begin{tabular}{|c|c|c|c|c|c|c|c|c|c|}
\hline $\mathrm{A}$ & $0-8$ & 0 & 7.1 & 6.8 & 18.17 & 13.4 & 3.39 & 84.01 & \\
\hline \multicolumn{9}{|c|}{$\begin{array}{l}\text { 11. Pióro (Nosal), } 950 \mathrm{~m} \text { a.s.l., ledge within rock slope } 20^{\circ} \mathrm{N} \text {, Erico-Pinetalia, } \\
\text { Eutric Lithic LEPTOSOL (Hyperhumic) }\end{array}$} & (unpublished) \\
\hline$\overline{\mathrm{O}}$ & $2-10$ & 0 & 5.6 & 5.0 & 48.17 & 28.0 & n.d. & n.d. & \\
\hline
\end{tabular}


Raw rocky rendzinas occuring on legdes in the rocky walls and on the rocky slopes are also diverse. In the vicinity of mountain tops, they are usually very shallow, because they are frequently eroded. Soil material moves to lower lying places, where deeper soils are formed. Within rocky wall the thickness of these soils depends on the size of the ledges. Mostly they are classified as raw rocky soils. These rendzinas are usually poorly stabilized (loose and friable consistence). Their physical and chemical properties mostly depend on the moisture conditions and the properties of a material deposited on the ledge. Both the SOC and carbonates concentration in rendzinas is lower in the case of substantial admixture of granitoides and metamorphic schists originating in higher positions in slope (profiles 6 and 7) (Table 2) in comparison to rendzinas developed from "pure' calcareous parent material (profiles 8 and 9) (Table 2).

Both organic $\mathrm{O}$ horizons and humus A horizons with a high content of SOC (profiles 10 and 11) (Table 2) formed 'in situ' can also found on ledges in the rocky wall and on the tops of calcareous rocks. Such soils occur, among others, in the relict pine forests (Erico-Pinetalia), which are very important plant communities for the biodiversity of the Tatra Mountains. Raw rocky rendzinas developed on 'pure' calcareous parent material create habitat for plant communities typical for calcareous grasslands (Festuco versicoloris-Seslerietum tatrae, CariciFestucetum tatrae), whereas in the case of substantial admixture of non-calcareous parts in soil some acidophilus plant species can be observed.
Raw debris rendzinas and debris proper rendzinas (Rędziny inicjalne rumoszowe i rędziny właściwe rumoszowe)

That group of rendzinas includes soils developed on talus cones and talus slopes. They occur presumably above timberline, in the Alpine and sub-Alpine zone in Tatra (profiles 12-14) (Table 3). The largest patches of raw debris rendzinas and debris proper rendzinas can be found in valleys: Litworowa, Mułowa and Wielka Świstówka in the Czerwone Wierchy massif. A much smaller talus cones are located in the forest belt (profile 15) (Table 3). A characteristic feature of raw debris rendzinas is the very high content of stones (even boulders) with varying thickness of solum. They often have a significant thickness, but simultaneously they have poorly (raw debris rendzinas) or moderately (debris proper rendzinas) developed soil genetic horizons. The variety of their physical and chemical properties is related to: (1) the content and size of the stony material, (2) the content and spatial distribution of fine-earth particles in solum, (3) the relief position of soil, (4) the moisture condition, and (5) the degree of surface stabilization (Miechówka 2000).

In the rendzinas occurring on talus slope directly at the foot of the rocky wall (profile 13) (Table 3) the content of SOC is usually higher, whereas the concentration of carbonates in the fine soil is usually lower in comparison to rendzinas occurring at higher distance from rocky wall (profiles 12, 14 and 15), although this phenomenon also depends on the degree of surface stabilization (Table 3). Plant communities such as: Silenietum prostratae, Oxyrio

TABLE 3. Basic properties of raw debris rendzinas and debris proper rendzinas

\begin{tabular}{|c|c|c|c|c|c|c|c|c|c|c|c|}
\hline \multirow[t]{2}{*}{ Horizon } & \multirow{2}{*}{$\frac{\text { Depth }}{\mathrm{cm}}$} & \multirow{2}{*}{$\frac{>2 \mathrm{~mm}}{\% \mathrm{v} / \mathrm{v}}$} & \multirow{2}{*}{$\begin{array}{l}\text { Colour } \\
\text { (moist) }\end{array}$} & \multirow{2}{*}{ Texture } & \multirow{2}{*}{$\frac{\mathrm{pH}}{\left(\mathrm{H}_{2} \mathrm{O}\right)}$} & \multirow{2}{*}{$\begin{array}{l}\mathrm{pH} \\
(\mathrm{KCl})\end{array}$} & \multirow{2}{*}{$\begin{array}{l}\text { SOC } \\
\%\end{array}$} & \multirow[t]{2}{*}{$\mathrm{C} / \mathrm{N}$} & \multicolumn{2}{|c|}{$\mathrm{eqCaCO}_{3} \mathrm{BS}$} & \multirow[t]{2}{*}{ Reference } \\
\hline & & & & & & & & & $\%$ & & \\
\hline \multicolumn{12}{|c|}{ 12. Krzesanica, 2,090 $\mathrm{m}$ a.s.l., talus cone $20^{\circ} \mathrm{W}$, Thlaspietalia, Calcaric Hyperskeletic LEPTOSOL } \\
\hline $\mathrm{AC}$ & $0-15$ & 80 & $10 \mathrm{YR} 7 / 2$ & - & 7.8 & 7.6 & 1.87 & 8.9 & 74.48 & 94.8 & (unpublished) \\
\hline \multicolumn{11}{|c|}{$\begin{array}{l}\text { 13. Małołaczniak, } 1,940 \mathrm{~m} \text { a.s.l., talus cone } 10^{\circ} \mathrm{NWW} \text {, Thlaspietalia Oxyrio digynae-Papaveretum tatrici, } \\
\text { Hyperskeletic Rendzic LEPTOSOL (Loamic, Hyperhumic) }\end{array}$} & \multirow[t]{4}{*}{ (unpublished) } \\
\hline $\mathrm{AC} 1$ & $0-14$ & 80 & 10YR 2/1 & - & 7.5 & 7.1 & 8.26 & 17.6 & 5.05 & 97.9 & \\
\hline $\mathrm{AC} 2$ & $14-31$ & 90 & 10YR 3/1 & $\mathrm{SL}$ & 8.0 & 7.2 & 8.91 & - & 3.41 & 98.5 & \\
\hline $2 \mathrm{AC}$ & $31-40$ & 75 & 10YR 2/1 & SL & 8.1 & 7.1 & 6.84 & - & 1.36 & 98.9 & \\
\hline \multicolumn{11}{|c|}{$\begin{array}{l}\text { 14. Mała Ś wistówka, } 1,360 \mathrm{~m} \text { a.s.l., talus cone } 10^{\circ} \mathrm{NE} \text {, Seslerietalia variae, } \\
\text { Calcaric Hyperskeletic LEPTOSOL (Humic) }\end{array}$} & \multirow[t]{3}{*}{ (unpublished) } \\
\hline $\mathrm{AC}$ & $0-16$ & 85 & 10 YR $4 / 3$ & - & 7.7 & 7.3 & 2.30 & 13.5 & 17.45 & 97.8 & \\
\hline Cca & 16-(33) & 90 & 10 YR $5-4 / 3$ & - & 7.9 & 7.4 & 1.67 & - & 20.11 & 97.8 & \\
\hline \multicolumn{11}{|c|}{$\begin{array}{l}\text { 15. Jastrzębia Turnia, } 1,080 \mathrm{~m} \text { a.s.l., debris slope } 15^{\circ} \mathrm{W} \text {, Carici-Festucetum tatrae, } \\
\text { Hyperskeletic Rendzic LEPTOSOL (Humic) }\end{array}$} & \multirow{3}{*}{$\begin{array}{l}\text { Niemyska- } \\
\text { Łukaszuk and } \\
\text { Miechówka } \\
\text {-(1996) }\end{array}$} \\
\hline \multirow{2}{*}{$\begin{array}{l}\mathrm{AC} \\
\mathrm{Cca}\end{array}$} & \multirow{2}{*}{$\begin{array}{l}0-23 \\
23-43\end{array}$} & \multirow{2}{*}{$\begin{array}{l}70 \\
95\end{array}$} & \multirow{2}{*}{$\begin{array}{l}\text { 10YR 2/1 } \\
10 Y R \text { 4/4 }\end{array}$} & \multirow{2}{*}{$\begin{array}{l}- \\
-\end{array}$} & 6.9 & 6.7 & 6.47 & 15.0 & 63.90 & 96.7 & \\
\hline & & & & & 7.2 & 7.0 & 1.21 & 6.3 & 88.34 & 97.9 & \\
\hline
\end{tabular}


digynae-Papaveretum tatrici and Cerastio latifoliiPapaveretum tatrici are developed on relatively mobile, active parts of talus cones. In contrast there are species characteristic for typical calcareous grasslands (forming plant communities such as: Festuco versicoloris-Seslerietum tatrae, Carici-Festucetum tatra) in the stabilized parts of talus cones, usually on the debris proper rendzinas. Raw debris rendzinas and debris proper rendzinas can also be found in the forest belt. They were described in coniferous spruce forest in the talus cone and talus slope in Wantule in Miętusia valley (Skiba et al. 2011). Thick ectohumus horizons cover a huge (calcareous) boulder and stones in this area. The content of rock fragments in soils reaches $90 \%$, and voids between them are partially filled by fine-earth particles containing up to $75 \%$ of soil organic matter (Skiba et al. 2011).

Typical proper rendzinas and humus rendzinas (Rędziny właściwe typowe oraz rędziny próchniczne)

Typical proper rendzinas and humus rendzinas occur at different elevations and under different vegetation (Table 4). They create habitats for plant communities such as: dwarf-pine shrubs (Pinetum mugo carpaticum), grasslands (Seslerietalia variae and Arrhenatheretalia elatioris), both natural broadleaf and coniferous forests (Dentario glandu-

TABLE 4. Basic properties of typical proper rendzinas and humus rendzinas

\begin{tabular}{|c|c|c|c|c|c|c|c|c|c|c|c|}
\hline \multirow[t]{2}{*}{ Horizon } & Depth & $>2 \mathrm{~mm}$ & \multirow{2}{*}{$\begin{array}{r}\text { Colour } \\
\text { (moist) }\end{array}$} & \multirow[t]{2}{*}{ Texture } & \multirow{2}{*}{$\frac{\mathrm{pH}}{\left(\mathrm{H}_{2} \mathrm{O}\right)}$} & \multirow{2}{*}{$\begin{array}{l}\mathrm{pH} \\
(\mathrm{KCl})\end{array}$} & \multirow{2}{*}{$\begin{array}{l}\text { SOC } \\
\% \\
\end{array}$} & \multirow[t]{2}{*}{$\mathrm{C} / \mathrm{N}$} & \multicolumn{2}{|c|}{$\mathrm{eqCaCO}_{3} \quad \mathrm{BS}$} & \multirow{2}{*}{$\begin{array}{l}\text { Reference / } \\
\text { Remarks }\end{array}$} \\
\hline & $\mathrm{cm}$ & $\% \mathrm{v} / \mathrm{v}$ & & & & & & & $\%$ & & \\
\hline \multicolumn{11}{|c|}{$\begin{array}{l}\text { 16. Bobrowiec, } 1,630 \mathrm{~m} \text { a.s.l., slope } 5^{\circ} \mathrm{N} \text {, Pinetum mugo carpaticum, Dolomitic Skeletic Leptic REGOSOL } \\
\text { (Loamic, Humic) }\end{array}$} & $\begin{array}{l}\text { Miechówka } \\
(2001)\end{array}$ \\
\hline OL & $0-1.5$ & 0 & - & - & 3.7 & 3.7 & 40.45 & 39.3 & 0.00 & 21.6 & \\
\hline Of & $1.5-3.5$ & 0 & - & - & 4.2 & 3.8 & 21.96 & 15.4 & 1.29 & 19.5 & \\
\hline A1 & $3.5-10$ & 0 & $10 \mathrm{YR} 3 / 3$ & $\mathrm{~L}$ & 4.9 & 3.9 & 7.14 & 13.2 & 1.09 & 45.2 & \\
\hline $\mathrm{A} 2$ & 10-19 & 15 & $10 \mathrm{YR} 4 / 3$ & $\mathrm{~L}$ & 6.0 & 5.8 & 4.74 & 10.5 & 2.59 & 86.9 & \\
\hline $\mathrm{AC}$ & $19-40$ & 90 & $5 \mathrm{Y} 6 / 1$ & $\mathrm{~L}$ & 7.3 & 6.8 & 2.28 & 15.2 & 49.32 & 95.3 & \\
\hline \multicolumn{11}{|c|}{$\begin{array}{l}\text { 17. Kopa Królowa Wielka, } 1,530 \text { m a.s.l., slope } 8^{\circ} \mathrm{N} \text {, Seslerietalia, Skeletic Somerirendzic LEPTOSOL } \\
\text { (Loamic, Humic }\end{array}$} & $\begin{array}{l}\text { Miechówka } \\
(2001)\end{array}$ \\
\hline A1 & $0-6$ & 20 & $10 \mathrm{YR} 3 / 2$ & $\mathrm{SiL}$ & 6.6 & 6.2 & 8.30 & 10.2 & 3.25 & 92.7 & \\
\hline A2 & $6-11$ & 20 & $10 \mathrm{YR} 3 / 3$ & SiL & 7.1 & 6.6 & 5.92 & 9.0 & 5.02 & 96.3 & \\
\hline Cca & $11-23$ & 85 & $10 \mathrm{YR} 4 / 4$ & SiL & 7.6 & 7.0 & 1.74 & 7.6 & 58.95 & 97.1 & \\
\hline
\end{tabular}

18. Opalony Wierch, $1,430 \mathrm{~m}$ a.s.l., slope $60^{\circ} \mathrm{S}$, Caricetum firmae, Dolomitic Somerirendzic Skeletic LEPTOSOL (Loamic, Hyperhumic)

\begin{tabular}{lccllllrrrr}
\hline Olf & $0-1$ & 0 & - & - & 5.8 & 5.3 & 21.62 & 18.0 & 1.70 & - \\
A & $1-8$ & 0 & 10YR 2/1 & - & 6.7 & 6.0 & 10.42 & 12.0 & 1.23 & - \\
AC & $8-18$ & 40 & 10YR 3/2 & - & 7.2 & 6.4 & 6.31 & 11.0 & 3.84 & - \\
Cca & $18-25$ & 80 & 10YR 6/4 & SiL & 7.9 & 7.1 & 0.49 & 6.0 & 68.02 & -
\end{tabular}

19. Bobrowiec, $1,485 \mathrm{~m}$ a.s.l., slope $60^{\circ} \mathrm{S}$, Caricetum firmae, Skeletic Endoleptic Rendzic PHAEOZEM Miechówka (Loamic)

\begin{tabular}{lrrrlrrrrrr}
\hline A1 & $0-12$ & 5 & 10YR 2/2 & - & 6.8 & 6.5 & 10.64 & 13.6 & 13.20 & 94.6 \\
A2 & $12-23$ & 15 & 10YR 3/3 & SL & 7.2 & 6.9 & 4.42 & 7.4 & 20.16 & 98.6 \\
AC & $23-34$ & 60 & 10YR 3/4 & SL & 7.3 & 7.0 & 2.34 & 4.4 & 76.09 & 97.3 \\
Cca & $34-52$ & 90 & 10YR 4/4 & SL & 7.4 & 7.1 & 0.75 & 4.7 & 86.23 & 96.4 \\
\hline
\end{tabular}

20. Głębowiec, $1,280 \mathrm{~m}$ a.s.l., slope $45^{\circ} \mathrm{NW}$, Piceetum tatricum - windthrow, Dolomitic Skeletic Epileptic Rendzic PHAEOZEM (Loamic)

\begin{tabular}{lccllllrrrr}
\hline A1 & $0-2$ & 0 & - & - & 7.1 & 6.4 & 16.11 & 15 & 3.52 & - \\
A2 & $2-12$ & 0 & 10YR 2/1 & - & 7.4 & 6.5 & 14.30 & 13 & 3.00 & - \\
AC & $12-22$ & 30 & 10YR 3/2 & - & 7.6 & 6.9 & 7.44 & 12 & 24.75 & - \\
Cca & $22-42$ & 80 & 10YR 5/4 & SiL & 8.0 & 7.0 & 0.84 & 9 & 80.91 & -
\end{tabular}

21. Polana Jaworzynka, 1,240 m a.s.l., slope $10^{\circ} \mathrm{NW}$, semi-natural meadows with elements of calcareous grassland, Miechówka Skeletic Epileptic Rendzic PHAEOZEM (Loamic)

\begin{tabular}{|c|c|c|c|c|c|c|c|c|c|c|c|}
\hline A & $0-10$ & 5 & $10 \mathrm{YR} 3 / 2$ & SL & 7.4 & 7.1 & 6.38 & 12.5 & 16.2 & 89.0 & / very moist \\
\hline $\mathrm{AC}$ & $10-33$ & 60 & $10 \mathrm{YR} 3 / 3$ & SL & 7.6 & 7.3 & 2.68 & 9.6 & 22.43 & 89.0 & \\
\hline \multicolumn{11}{|c|}{$\begin{array}{l}\text { 22. Polana Smytnia, 1, } 115 \mathrm{~m} \text { a.s.l., slope } 20^{\circ} \mathrm{WNW}, \text { Gladiolo-Agrostietum, Calcaric Skeletic Endoleptic } \\
\text { PHAEOZEM (Loamic) }\end{array}$} & \multirow{4}{*}{$\begin{array}{l}\text { Miechówka } \\
\text { (1994) } \\
\text { - / very moist }\end{array}$} \\
\hline A1 & $0-13$ & 5 & $10 \mathrm{YR} 3 / 2$ & - & 6.6 & 5.9 & 8.62 & 8.9 & 1.09 & 82.7 & \\
\hline $\mathrm{A} 2$ & $13-23$ & 20 & $10 \mathrm{YR} 3 / 3$ & SiL & 7.1 & 6.7 & 4.82 & 11.4 & 14.16 & 94.4 & \\
\hline $\mathrm{Cca}$ & $23-66$ & 90 & $10 Y R 4 / 3$ & SiL & 7.5 & 7.2 & 1.86 & 8.5 & 22.32 & 95.3 & \\
\hline
\end{tabular}


losae-Fagetum, Sorbo-Aceretum, Polysticho-Piceetum tatricum) and artificial spruce monocultures.

In these soils, various subtypes of mull and amphi humus types are present (sensu Jabiol et al. 2013). A relatively large amount of well-humified organic matter in humus horizons gives them a black colour (Table 4). Proper rendzinas and humus rendzinas are different in thickness of humus horizons (Table 4). However, regardless soil type, some of them have neutral or slightly alkaline reaction in whole solum (pH in water 7.1-8.0) (e.g. profiles 20 and 21) (Table 4), whereas some others are acidic in the uppermost part of soil (lower $\mathrm{pH}$, less carbonates content or even lack of them). A well-pronounced acidification of humus horizons is evident in the rendzinas under the coniferous forests and under dwarf-pine shrubs, in circumstances such that soils is covered by low thickness litter (profile 16) (Table 4). The slightly acidic, neutral or slightly alkaline reaction $\mathrm{pH}$ in water 5.6-7.8) can also be found in some soils of grasslands (including glades) (profiles 17, 18 and 22) (Table 4). Detailed chemical and micromorphological studies of soils with acidic uppermost part of solum carried out by Miechówka (2000) have shown that these soils are characterized by (1) high biological activity; (2) soil plasma formed microforms typical for brown rendzinas (skel-lattisepic, lattisepic) and (3) a higher content of aluminosilicate iron in comparison with other rendzinas.

\section{Raw-humus rendzinas (Rędziny butwinowe)}

Raw-humus rendzinas occur in places favouring the accumulation of organic matter on the soil surface (litter). Those are usually high-elevated areas, with high precipitation and low temperature, fully covered with vegetation cover, where the intensity of morphogenetic processes is negligible. Thick organic soil horizons develop under such conditions. Conventionally rendzinas with folic horizon (thickness of $\geq 10 \mathrm{~cm}$ and $<40 \mathrm{~cm}$ ) over A or AC horizon are classified as raw-humus rendzinas. These soils occur in the Alpine and in the sub-Alpine zone, as well as in the montane belt. Vegetation has a crucial role in shaping thickness, biological activity and chemical properties of organic $\mathrm{O}$ horizons in these soils.

Rendzinas with tangel humus usually occur under natural upper-montane coniferous spruce forests (Polysticho-Piceetum). In these soils, called tangelrendzinas, the thickness of organic $\mathrm{O}$ horizons is more than twice the thickness of humus A horizons (Table 5). Organic $\mathrm{O}$ horizons consist of both well-pronounced poorly-humified organic matter (horizons: $\mathrm{Ol}, \mathrm{Of}$ ) and well-humified organic matter (horizon Oh) (profile 23) (Table 5). The organic O horizons in these soils are acidic or strongly acidic $(\mathrm{pH}$ in water $<5.5)$ and do not contain carbonates.

Raw-humus rendzinas with pachyamphi humus type occur under the calcareous grasslands Seslerietalia varia (profiles 24, 25 and 26) (Table 5). These soils, called amphi-rendzinas, can be also found under the artificial spruce monoculture (profile 27) (Table 5). They have relatively thick organic $\mathrm{O}$ horizons, dominated by well-humified organic matter $(\mathrm{Oh}$ horizon). Below occurs humus A horizon with a thickness of more than half the thickness of $\mathrm{Oh}$ horizons. The $\mathrm{pH}$ values in the organic horizons of amphi-rendzinas are usually higher than in tangelrendzinas. Under dwarf-pine shrubs both tangelrendzinas (profile 28) (Table 5) and amphi-rendzinas can be found (profile 29) (Table 5). Due to special genetic conditions raw-humus rendzinas are recognized in Alps and Tatra as high-mountainous variants of rendzinas.

\section{Brown rendzinas (Rędziny brunatne)}

Brown rendzinas have been found in all climatic and vegetation zones in the Tatra Mountains, with the exception of bare rocky belt. They occupy the largest area in the montane belt (Komornicki 1977), including glades (Miechówka 1994). Brown rendzinas above the upper timberline are located in the elevation zone ca. 1550-1750 m a.s.l. (Miechówka 2000). They are most often located on southern exposed slopes, where the admixture of aeolian material is significant. They have also developed on the slope covers containing a significant amount of non-carbonate rocks admixture (Table 6).

The weathering process leading to formation of Bw horizon, correlated with cambic horizon (so-called 'brownification'), may occur in Tatra even in soil containing up to $30 \%$ carbonates in the fine-earths provided that: (1) the proportion of active carbonates is small $(0-10 \%),(2)$ they contain the appropriate amount of iron, and (3) the biological activity of soils (including soil meso-fauna) is high (Miechówka 2000). Brown rendzinas can be found in forests often under the broadleaf Dentario glandulosae-Fagetum, and under grasslands such us a Gladiolo-Agrostietum plant community (e.g. profiles 30 and 31) (Table 6). Above the upper timberline, these soils form habitats for calcareous grasslands Seslerietalia variae (e.g. profile 32), grassland Calamagrostietalia villosae (e.g. profile 33) and dwarf-pine shrubs Pinetum mugo carpaticum (e.g. profile 34) (Table 6). 
TABLE 5. Basic properties of raw humus rendzinas

\begin{tabular}{|c|c|c|c|c|c|c|c|c|c|c|c|}
\hline \multirow{2}{*}{ Horizon } & \multirow{2}{*}{$\frac{\text { Depth }}{\mathrm{cm}}$} & \multirow{2}{*}{$\frac{>2 \mathrm{~mm}}{\% \mathrm{v} / \mathrm{v}}$} & \multirow{2}{*}{$\begin{array}{r}\text { Colour } \\
\text { (moist) }\end{array}$} & \multirow[t]{2}{*}{ Texture } & \multirow{2}{*}{$\frac{\mathrm{pH}}{\left(\mathrm{H}_{2} \mathrm{O}\right)}$} & \multirow{2}{*}{$\frac{\mathrm{pH}}{(\mathrm{KCl})}$} & \multirow{2}{*}{$\frac{\mathrm{SOC}}{\%}$} & \multirow[t]{2}{*}{$\mathrm{C} / \mathrm{N}$} & \multicolumn{2}{|c|}{$\mathrm{eqCaCO}_{3} \mathrm{BS}$} & \multirow{2}{*}{$\begin{array}{l}\text { Reference / } \\
\text { Remarks }\end{array}$} \\
\hline & & & & & & & & & $\%$ & $\%$ & \\
\hline \multicolumn{11}{|c|}{$\begin{array}{l}\text { 23. Dolina Miętusia, } 1,170 \mathrm{~m} \text { a.s.l., slope } 20^{\circ} \mathrm{E} \text {, Polysticho-Piceetum, Dolomitic Skeletic Folic } \\
\text { Leptic REGOSOL (Loamic) }\end{array}$} & \multirow{5}{*}{$\begin{array}{l}\text { Miechówka (1989) } \\
\text { / Humus form: } \\
\text { Eutangel } \\
\text { / very moist - wet }\end{array}$} \\
\hline Olf & $0-3$ & 0 & - & - & 5.7 & 5.2 & 37.48 & 22 & 2.95 & - & \\
\hline $\mathrm{Oh}$ & $3-20$ & 0 & 10YR $2 / 1$ & - & 5.7 & 5.2 & 31.29 & 19 & 1.11 & - & \\
\hline A & $20-24$ & 30 & $10 \mathrm{YR} 3 / 2$ & SL & 7.5 & 6.9 & 7.16 & 15 & 44.91 & - & \\
\hline Cca & $24-39$ & 90 & $10 \mathrm{YR} 4 / 4$ & SL & 7.7 & 7.0 & 1.52 & 11 & 75.82 & - & \\
\hline
\end{tabular}

24. Stoły, 1,940 m a.s.l., shoulder $25^{\circ} \mathrm{W}$, Festuco versicoloris-Seslerietum tatrae, Dolomitic Folic LEPTOSOL (Humic)

\begin{tabular}{lcccccccccccc}
\hline Oh & $0-11$ & 0 & 10YR 3/1 & - & 6.0 & 5.6 & 20.62 & 12.6 & 0.00 & - & / Humus form: \\
A & $11-18$ & 0 & 10YR 3/2 & - & 6.9 & 6.2 & 7.62 & 10.0 & 0.00 & 95.4 & Pachyamphi \\
Cca & $18-24$ & 90 & 10YR 6/2 & - & 7.8 & 7.7 & 1.35 & 15.0 & 88.39 & 98.6 & / very moist
\end{tabular}

25. Kominiarski Wierch, 1,829 $\mathrm{m}$ a.s.1., summit $3^{\circ} \mathrm{W}$, mixed high-mountain grassland, Folic Endoleptic Rendzic PHAEOZEM (Hyperhumic)

\begin{tabular}{lcclllllllll}
\hline Oh1 & $0-13$ & 0 & 10YR 2/1 & - & 5.4 & 4.9 & 30.42 & 16.0 & 0.00 & 77.4 & $(1998)$ \\
Oh2 & $13-26$ & 0 & 10YR 2/1 & - & 5.8 & 5.0 & 23.32 & 21.0 & 0.02 & 69.3 & / Humus form: \\
AC & $26-63$ & 60 & 10YR 2/1 & - & 6.5 & 6.1 & 14.84 & 19.7 & 5.91 & 91.1 & $\begin{array}{l}\text { Pachyamphi } \\
\text { / very moist }\end{array}$
\end{tabular}

26. Mnichy Chochołowskie, 1,470 $\mathrm{m}$ a.s.l., slope $75^{\circ} \mathrm{S}$, Seslerietalia variae, Calcaric Folic Hyperskeletic LEPTOSOL (Arenic)

\begin{tabular}{|c|c|c|c|c|c|c|c|c|c|c|c|}
\hline $\mathrm{O}$ & $0-13$ & 20 & 10YR 2/1 & - & 7.3 & 7.0 & 26.70 & 25.0 & 47.34 & 98.1 & Pachyamphi \\
\hline $\mathrm{OC}$ & $13-22$ & 70 & 10YR 3/1 & - & 7.5 & 7.2 & 19.05 & 19.2 & 70.00 & 97.6 & \\
\hline $\mathrm{AC} 1$ & $22-40$ & 85 & 10YR 4/4 & $\mathrm{S}$ & 7.8 & 7.4 & 4.52 & 8.5 & 91.57 & 93.7 & \\
\hline $\mathrm{AC} 2$ & $40-57$ & 90 & $10 Y R$ 5-4/4 & $\mathrm{S}$ & 8.1 & 7.7 & 2.79 & 6.8 & 95.32 & 94.8 & \\
\hline
\end{tabular}
27. Dolina Białego, 980 m a.s.l., middle slope - flat, spruce monoculture, Calcaric Skeletic Wasak (2013,
Folic Endoleptic PHAEOZEM (Hyperhumic)

\begin{tabular}{lllllllllll}
\hline O1 & $0-1$ & 0 & - & - & 5.5 & 5.0 & 53.83 & - & - & - \\
Of & $1-7$ & 0 & - & - & 4.6 & 3.7 & 52.32 & 24 & 0.00 & 29 \\
Oh1 & $7-14$ & 0 & - & - & 6.3 & 5.7 & 32.48 & 22 & 0.19 & 15 \\
Oh2 & $14-24$ & 5 & $7.5 Y R ~ 1.7 / 1$ & - & 7.2 & 6.7 & 21.03 & 19 & 19.43 & 86 \\
AC1 & $25-30$ & 50 & $7.5 Y R ~ 1.7 / 1$ & - & 7.2 & 6.7 & 16.63 & 20 & 24.61 & 97 \\
AC2 & $30-40$ & 60 & 10YR 1.7/1 & SiL & 7.3 & 6.8 & 8.77 & 16 & 37.86 & 92 \\
AC3 & $40-50$ & 75 & 10YR 2/2 & - & 7.4 & 6.9 & 5.78 & 11 & 29.09 & - \\
\hline
\end{tabular}

28. Dolina Kondracka, 1,560 m a.s.l., bottom of valley $5^{\circ} \mathrm{N}$, Pinetum mugo carpaticum, Drewnik (1998) Folic Epileptic Somerirendzic PHAEOZEM (Hyperhumic)

\begin{tabular}{|c|c|c|c|c|c|c|c|c|c|c|c|}
\hline $\mathrm{Ol}$ & $0-1$ & 0 & - & - & - & - & - & - & - & - & \multirow[t]{4}{*}{ Dystangel } \\
\hline Ofh & $1-16$ & 0 & $10 Y R$ 2/2 & - & 4.2 & 3.6 & 37.51 & 30 & - & 32 & \\
\hline $\mathrm{Oh}$ & $16-25$ & 0 & 10YR 1.7/1 & - & 4.6 & 4.0 & 31.04 & - & - & - & \\
\hline $\mathrm{Ah}$ & $25-35$ & 10 & 7.5YR 2/1 & - & 7.3 & 6.9 & 5.83 & - & - & - & \\
\hline \multicolumn{11}{|c|}{$\begin{array}{l}\text { 29. Kominiarski Wierch, } 1,825 \mathrm{~m} \text { a.s.l., middle slope } 8^{\circ} \mathrm{N} \text {, Pinetum mugo carpaticum, } \\
\text { Skeletic Folic Epileptic Rendzic PHAEOZEM (Hyperhumic) }\end{array}$} & \multirow{5}{*}{$\begin{array}{l}\text { Miechówka (2002) } \\
\text { / Humus form: } \\
\text { Pachyamphi }\end{array}$} \\
\hline Olf & $0-2$ & 0 & - & - & 5.1 & 4.0 & 37.05 & 20.6 & 0.00 & 17.2 & \\
\hline Oh1 & $2-4$ & 0 & $10 \mathrm{YR} 2 / 2$ & - & 5.8 & 4.7 & 28.57 & 13.8 & 1.11 & 48.1 & \\
\hline $\mathrm{Oh} 2$ & $4-14$ & 0 & 7.5YR 2/1 & - & 6.7 & 6.7 & 27.02 & 19.7 & 1.32 & 95.9 & \\
\hline $\mathrm{AC}$ & $14-39$ & 90 & 7.5YR 2/1 & - & 7.3 & 6.8 & 12.72 & 18.9 & 2.95 & 98.0 & \\
\hline
\end{tabular}

\section{CONCLUSIONS}

Tatra rendzinas are diverse soils in terms of both morphology and properties (physical, chemical and biological ones). They are a base of various biotopes and they have a great importance in shaping the biodiversity of the Tatra Mountains, creating a number of important habitats. The diversity of these soils is determined by spatially varied and changing with altitude factors such as: parent rock, geomorphological processes, climatic conditions and vegetation. Due to the strong influence of morphogenetic processes and climatic factors, a special attention has been paid to the specific pattern of the Tatra rendzinas soil cover ('open-work' type). Another important feature of the Tatra rendzinas is the extremely high content of SOC 
TABLE 6. Basic properties of brown rendzinas

\begin{tabular}{|c|c|c|c|c|c|c|c|c|c|c|c|}
\hline \multirow[t]{2}{*}{ Horizon } & Depth & $>2 \mathrm{~mm}$ & \multirow[t]{2}{*}{ Colour (moist) } & \multirow[t]{2}{*}{ Texture } & \multirow{2}{*}{$\mathrm{pH}$} & \multirow{2}{*}{$\mathrm{pH}$} & \multirow{2}{*}{$\begin{array}{l}\text { SOC } \\
\end{array}$} & \multirow[t]{2}{*}{$\mathrm{C} / \mathrm{N}$} & \multicolumn{2}{|c|}{$\mathrm{eqCaCO}_{3} \mathrm{BS}$} & \multirow[t]{2}{*}{ Reference } \\
\hline & $\mathrm{cm}$ & $\% \mathrm{v} / \mathrm{v}$ & & & & & & & $\%$ & $\%$ & \\
\hline \multicolumn{11}{|c|}{$\begin{array}{l}\text { 30. Polana Stoły, } 1,350 \mathrm{~m} \text { a.s.l., slope } 15^{\circ} \mathrm{E}, \text { Gladiolo-Agrostietum, Calcaric Epileptic } \\
\text { CAMBISOL (Loamic, Humic) }\end{array}$} & $\begin{array}{l}\text { Miechówka } \\
\text { (1994) }\end{array}$ \\
\hline $\mathrm{A}$ & $0-12$ & 0 & $10 Y R 3 / 3$ & SiL & 5.4 & 4.7 & 5.63 & 10.6 & 0.00 & 59.4 & \\
\hline $\mathrm{Bw}$ & $12-23$ & 0 & 10YR 4/3 & $\mathrm{SiL}$ & 6.6 & 6.4 & 1.84 & - & 9.75 & 85.8 & \\
\hline $\mathrm{BC}$ & $23-37$ & 80 & $10 \mathrm{YR} 4 / 2$ & $\mathrm{SiL}$ & 7.4 & 7.2 & 0.75 & - & 54.29 & 94.9 & \\
\hline \multicolumn{11}{|c|}{$\begin{array}{l}\text { 31. Przysłop Miętusi, } 1,100 \mathrm{~m} \text { a.s.l., slope } 20^{\circ} \mathrm{SW} \text {, Gladiolo-Agrostietum, Calcaric Skeletic Endoleptic } \\
\text { CAMBISOL (Loamic, Humic, Raptic) }\end{array}$} & $\begin{array}{l}\text { Miechówka } \\
(1994)\end{array}$ \\
\hline A & $0-27$ & 5 & 10YR 4/4 & - & 6.8 & 6.5 & 7.49 & - & 2.20 & 92.3 & \\
\hline $\mathrm{Bw}$ & $27-40$ & 15 & 10YR 5/8 & $\mathrm{L}$ & 7.6 & 7.0 & 1.74 & - & 9.93 & 97.2 & \\
\hline $2 \mathrm{BC}$ & $40-79$ & 90 & $10 \mathrm{YR} 5 / 3$ & $\mathrm{SiL}$ & 7.9 & 7.4 & 0.40 & - & 46.25 & 99.1 & \\
\hline \multicolumn{11}{|c|}{$\begin{array}{l}\text { 32. Mała Ś wistówka, } 1,570 \mathrm{~m} \text { a.s.l., ledge in the rock wall, } 80^{\circ} \mathrm{SSE} \text {, Seslerietalia variae, Eutric Epileptic } \\
\text { CAMBISOL (Loamic, Humic, Raptic) }\end{array}$} & $\begin{array}{l}\text { Miechówka } \\
(2001)\end{array}$ \\
\hline $\mathrm{A}$ & $0-10$ & 30 & $10 Y R 2 / 2$ & SL & 6.5 & 6.2 & 7.74 & 12.5 & 0.00 & 90.0 & \\
\hline $2 \mathrm{AB}$ & $10-22$ & 20 & 10YR 3/4 & SL & 7.0 & 6.5 & 5.37 & 12.2 & 0.00 & 91.1 & \\
\hline $2 \mathrm{Bw}$ & $22-35$ & 20 & $10 \mathrm{YR} 5 / 4$ & SL & 7.1 & 6.7 & 2.12 & 7.9 & 0.30 & 87.1 & \\
\hline \multicolumn{11}{|c|}{$\begin{array}{l}\text { 33. Zawrat Kasprowy, } 1,610 \mathrm{~m} \text { a.s.l., slope } 60^{\circ} \mathrm{N} \text {, Calamagrostietalia villosae, Eutric Leptic CAMBISOL } \\
\text { (Loamic, Humic) }\end{array}$} & $\begin{array}{l}\text { Miechówka } \\
\text { (1998) }\end{array}$ \\
\hline $\mathrm{Ah}$ & $0-10$ & 0 & 10 YR $3 / 2$ & - & 5.2 & 4.5 & 7.22 & 7.7 & 0.25 & 60.2 & \\
\hline $\mathrm{AB} 1$ & $10-30$ & 10 & 10YR $4 / 4$ & SL & 5.8 & 4.8 & 2.95 & 7.6 & 0.32 & 64.9 & \\
\hline $\mathrm{AB} 2$ & $30-50$ & 70 & $10 \mathrm{YR} 4 / 4$ & SL & 6.7 & 6.0 & 2.17 & 7.5 & 0.61 & - & \\
\hline \multicolumn{11}{|c|}{$\begin{array}{l}\text { 34. Kominiarski Wierch, } 1,545 \mathrm{~m} \text { a.s.l., slope } 60^{\circ} \mathrm{SSE} \text {, Pinetum mugo carpaticum, Calcaric Skeletic Epileptic } \\
\text { CAMBISOL (Loamic, Hyperhumic) }\end{array}$} & $\begin{array}{l}\text { Miechówka } \\
\text { (2002) }\end{array}$ \\
\hline $\mathrm{Ol}$ & $0-3$ & 0 & - & - & 4.3 & 3.7 & 44.58 & 45.9 & 0.00 & 17.5 & \\
\hline Ofh & $3-4.5$ & 5 & 10YR 2/2 & - & 4.4 & 3.9 & 26.30 & 17.4 & 1.32 & 30.7 & \\
\hline A & $4.5-10$ & 30 & 10YR 3-2/2 & - & 5.9 & 6.0 & 13.29 & 9.5 & 1.70 & 89.5 & \\
\hline $\mathrm{AB}$ & $10-20$ & 50 & 10YR 4/1 & - & 6.6 & 6.1 & 10.57 & 9.1 & 2.32 & 94.8 & \\
\hline $\mathrm{BC}$ & $20-45$ & 85 & 10YR 5/6 & SL & 7.6 & 7.0 & 1.84 & 7.7 & 30.84 & 98.5 & \\
\hline
\end{tabular}

and the occurrence of all types and subtypes of humus, which distinguishes the Tatra region from other parts of Poland.

Rendzinas in Tatra (especially variants called 'high-mountainous rendzinas') differ from rendzinas occurring in lowlands with respect to the content and the distribution of carbonates in soil body. In some rendzinas despite the high content of stones consisting of limestones, dolomites or marls in solum, carbonates are absent in fine earth material. In some cases, despite the high content of carbonates in fine earth, the process of weathering typical for cambic B horizon is taking place, possibly due to the low content of active carbonates.

Tatra rendzinas are widely studied soils (probably the best researched rendzinas in Poland). Despite this, they are still an interesting object of research. The problem of their classification is still under discussion. The unique characteristics of some rendzina units makes it problematic to allocate them to the established divisions. The proposal given in this paper could be an input in this debate.

\section{ACKNOWLEDGEMENTS}

The authors are grateful to the anonymous reviewer for their insightful and constructive comments that significantly increased the scientific quality of the paper.

\section{REFERENCES}

Adamczyk B., 1962a. Gleby tatrzańskie. [In:] Szafer W. (ed.) Tatrzański Park Narodowy. ZOP PAN Kraków: 149-166 (in Polish with English abstract).

Adamczyk B., 1962b. Studia gleboznawczo-fitosocjologiczne w Dolinie Małej Łąki w Tatrach. Acta Agraria et Silvestria, ser. Leśna 2: 45-116 (in Polish with English abstract).

Balon J., Jodłowski M., Krąż P., 2015. Tatry - regionalizacja fizycznogeograficzna [In:] K. Dąbrowska, M. Guzik (eds.), Atlas Tatr - Przyroda nieożywiona, Wydawnictwo Tatrzańskiego Parku Narodowego.

Barančok P., Varšavová M., 1996. The influence of tourism on the natural environment of the Belianske Tatry Mountains investigated on an educational hiking path situated in the locality of Monkova dolina - Kopské sedlo and its near surroundings. Ecology (Bratislava) 4: 469-473. 
Barančoková M., Barančok P., Mišovičová D., 2009. Heavy metal loading of the Belianske Tatry Mts, Ekológia (Bratislava) 28(3): 255-268.

Bedrna Z., Račko J., 1999. Soils in the Belianske Tatry Mts. Ústav krajinnej ekológie SAV, Bratislava: $22 \mathrm{pp}$.

Ciarkowska K., Miechówka A., 2005a. Aktywność biologiczna górskich rędzin próchnicznych wytworzonych ze skał węglanowych i gipsowych Dolomitów. Część I. Mikromorfometryczne wskaźniki aktywności fauny glebowej i aktywność dehydrogenaz. Problemy Zagospodarowania Ziem Górskich 52: 57-64 (in Polish with English abstract).

Ciarkowska K., Miechówka A., 2005b. Aktywność biologiczna górskich rędzin próchnicznych wytworzonych ze skał węglanowych i gipsowych Dolomitów. Część II. Wpływ aktywności fauny glebowej na skład frakcyjny połączeń próchnicznych. Problemy Zagospodarowania Ziem Górskich 52: 6570 (in Polish with English abstract).

Drewnik M., 1998. Tempo rozkładu materii organicznej w glebach górskich Karpat. Zeszyty Problemowe Postępów Nauk Rolniczych 464: 169-173 (in Polish with English abstract).

Drewnik M., 2006. The effect of environmental conditions on the decomposition rate of cellulose in mountain soils. Geoderma 132: 116-130.

Drewnik M., 2008. Geomorfologiczne uwarunkowania rozwoju pokrywy glebowej w obszarach górskich na przykładzie Tatr. Wydawnictwo UJ, Kraków: 118 pp. (in Polish with English abstract).

Dyduch-Falniowska A., 1991. The gastropods of the Polish. Tatra Mountains. Studia Naturae, Ser. A 38: 1-11.

Fabijanowski J., 1962. Lasy tatrzańskie. [In:] Szafer W. (ed.) Tatrzański Park Narodowy, ZOP PAN, Kraków: 240-304 (in Polish with English abstract).

Graefe U., 2007. Gibt es in Deutschland die Humusform Amphi? Mitteilungen der Deutschen Bodenkundlichen Gesellschaft 110: 459-460.

Habitat Directive Council Directive 92/43/EEC on the conservation of natural habitats and of wild fauna and flora, 1992.

Hess M., 1996. Klimat. [In:] Mirek Z. (ed.) Przyroda Tatrzańskiego Parku Narodowego. Tatry i Podtatrze 3: 53-68 (in Polish with English abstract).

Hreško J., Bugár G., Boltižiar M., Kohút F., 2008. The dynamics of recent geomorphic processes in the Alpine zone the Tatra Mountains. Geographia Polonica: Modelling of High-Mountain Relief 81(1): 53-66.

INRA 1992. Référentiel pédologique principaux sols d'Europe. Institut National de la Recherche Agronomique, Paris: 222 pp.

IUSS Working Group WRB, 2015. World Reference Base for soil resources 2014. International soil classification system for naming soils and creating legends for soil maps. Update 2015. World Soil Resources Report No. 106. FAO, Rome: $192 \mathrm{pp}$.

Jabiol B., Zanella A., Ponge J.F., Sartori G., Englisch M., van Delf B., de Waal R., Le Bayon R.C., 2013. A proposal for including humus forms in the World Reference Base for Soil Resources (WRB-FAO). Geoderma 192: 286-294.

Klimaszewski M., 1996. Geomorfologia. [In:] Mirek Z. (ed.) Przyroda Tatrzańskiego Parku Narodowego. Tatrzański Park Narodowy, Zakopane: 97-124 (in Polish with English abstract).

Komornicki T., 1977. Tatrzańskie rędziny strefy leśnej. Roczniki Gleboznawcze - Soil Science Annual 28(1): 277-291 (in Polish with English abstract).
Komornicki T., Adamczyk B., Firek A., Jakubiec J., NiemyskaŁukaszuk J., Oleksynowa K., Skiba S., Tokaj J., 1984a. Gleby Tatrzańskiego Parku Narodowego. Cz. II. Obszar środkowy od Kopieńców po Dolinę Kościeliską. Studia Ośrodka Dokumentacji Fizjograficznej PAN w Krakowie 12: 283-299 + mapa (in Polish with English abstract).

Komornicki T., Oleksynowa K., Skiba S., 1984b. Gleby Tatrzańskiego Parku Narodowego. Cz. III. Obszar Dolin Chochołowskiej i Lejowej. Studia Ośrodka Dokumentacji Fizjograficznej PAN w Krakowie 12: 283-300 (in Polish with English abstract).

Komornicki T., Baran S., Firek A., Jakubiec J., Niemyska-Łukaszuk J., Oleksynowa K., Skiba S., 1975. Gleby Tatrzańskiego Parku Narodowego. Cz. I. Obszar Wschodni od Doliny Białej Wody po Kopieńce. Studia Ośrodka Dokumentacji Fizjograficznej PAN w Krakowie 5: 100-130 + mapa (in Polish with English abstract).

Komornicki T., Skiba S., 1985. Gleby. [In:] Trafas K. (ed.) Atlas Tatrzańskiego Parku Narodowego. Wyd. TPN-PTPNoZ, Kraków-Zakopane, plansza 15.

Komornicki T., Skiba S., 1996. Soils. [In:] Mirek Z. (ed.) Przyroda Tatrzańskiego Parku Narodowego. Tatrzański Park Narodowy, Zakopane: 215-226 (in Polish with English abstract).

Koreň M., 1994. Vývoj poznávania pôd. [In:] Vološčuk I. (ed.) Tatranský Národný Park Biosferérická rezervácia. Wyd. Gradus, Martin: 78-85 (in Slovak).

Koreň M., Linkeš V., Bublinec E., 1994. Charakteristika pôd. [In:] Vološčuk I. (ed.) Tatranský Národný Park Biosferérická rezervácia. Wyd. Gradus, Martin: 86-105 (in Slovak).

Koreň M., Skiba S., Kukla J., 2010. Pody. [In:] Tatry - priroda. Wyd. Baset, Praha: 265-277 (in Slovak with English abstract).

Kotarba A., 1996. Współczesne procesy rzeźbotwórcze. Mirek Z. (ed.) Przyroda Tatrzańskiego Parku Narodowego. Tatrzański Park Narodowy, Zakopane: 125-138 (in Polish with English abstract).

Kubica B., Mietelski J.W., Gołaś J., Skiba S., Tomankiewicz E., Gaca P., Jasińska M., Tuteja-Krysa M., 2002. Concentration of $137 \mathrm{Cs}, 40 \mathrm{~K}, 238 \mathrm{Pu}$ and $239+240 \mathrm{Pu}$ radionuclides and some heavy metals in soil samples from the two main valleys from Tatra National Park. Polish Journal of Environmental Studies 11(5): 537-545.

Kubica B., Kwiatek W.M., Stobiński M., Skiba S., Skiba M., Gołaś J., Kubica M., Tuleja-Krysa M., Wrona A., Misiak R., 2007. Concentration of $137 \mathrm{Cs}, 40 \mathrm{~K}$ radionuclides and some heavy metals in soil samples from Chochołowska Valley from Tatra National Park. Polish Journal of Environmental Studies 16(5): 735-741.

Kubica B., Skiba S., Drewnik M., Stobiński M., Kubica M., Gołaś J., Misiak R., 2010. Radionuclides $137 \mathrm{Cs}$ and $40 \mathrm{~K}$ in the soils of the Tatra National Park (TPN, Poland). Nukleonika 55: 377-386.

Kubiena W.L., 1953. Bestimmungsbuch und Systematik der Böden Europas. Ferdinand Enke Verlag, Stuttgard: 392 pp.

Kubiena W.L., 1970. Alpine Soils on Limestone, Special Variations. [In:] Kubiena W.L. (ed.) Micromorphological features of soil geography. Rutgers Univ. Press., New Brunswick, NJ: 41-57.

Linkeš V., 1981. Geografia pôd Vysokých Tatier i ich predpolia. Geograficky Časopis 33(1): 32-49 (in Slovak with English abstract). 
Midriak R., 1971. Pôdne vlasnosti deštrukčných foriem v subalpinskom a alpinskom stupni Belanských Tatier. Geograficky Časopis 23(4): 316-337 (in Slovak with English abstract).

Midriak R., 1983. Morfogenéza povrchu vysokých pohorí. VEDA, Bratislava: 516 pp. (in Slovak).

Miechówka A., 1989. Charakterystyka geochemiczna rędzin tatrzańskich wytworzonych z dolomitów. Cz. I. Ogólna charakterystyka gleb i niektóre dane mineralogiczne. Roczniki Gleboznawcze - Soil Science Annual 40(2): 83-105 (in Polish with English abstract).

Miechówka A., 1990. Charakterystyka geochemiczna rędzin tatrzańskich wytworzonych z dolomitów. Cz. II. Właściwości chemiczne badanych gleb. Roczniki Gleboznawcze - Soil Science Annual 41(3/4): 29-48 (in Polish with English abstract).

Miechówka A., 1994. Gleby polan tatrzańskich. [In:] Mirek Z., Holeksa J., Miechówka A. (eds.) Zróżnicowanie i problemy ochrony roślinności i gleb polan Tatrzańskiego Parku Narodowego. Opracowanie powielone w Dyrekcji TPN (in Polish).

Miechówka A., 1998. Charakterystyka rędzin występujących powyżej górnej granicy lasu w Tatrach. Studia Ośrodka Dokumentacji Fizjograficznej PAN 25: 41-60 (in Polish with English abstract).

Miechówka A., 2000. Charakterystyka tatrzańskich gleb nieleśnych wytworzonych ze skał węglanowych. Zeszyty Naukowe AR w Krakowie, Rozprawy 263: 86 pp. (in Polish with English abstract).

Miechówka A., 2001. Zawartość różnych form żelaza w rędzinach położonych powyżej górnej granicy lasu w Tatrach. Roczniki Gleboznawcze - Soil Science Annual 52(supl.): 135-143 (in Polish with English abstract).

Miechówka A., 2002. Wybrane właściwości rędzin występujących pod kosodrzewiną w Tatrzańskim Parku Narodowym. Roczniki Gleboznawcze - Soil Science Annual 53(1-2): 1-8 (in Polish with English abstract).

Miechówka A., Ciarkowska K., 1998. Mikromorfologiczne formy próchnicy tatrzańskich rędzin próchnicznych i butwinowych. Zeszyty Problemowe Postępów Nauk Rolniczych 464: 161-168 (in Polish with English abstract).

Miechówka A., Ciarkowska K., 2002. Aktywność fauny glebowej w rędzinach organicznych i próchnicznych obszarów nieleśnych Tatrzańskiego Parku Narodowego. Przemiany środowiska przyrodniczego Tatr, Kraków-Zakopane 2002: 111115 (in Polish with English abstract).

Miechówka A., Głąb T., 1998. pH gleb różnych pięter klimatycznych w Tatrach Polskich. Zeszyty Problemowe Postępów Nauk Rolniczych 456: 489-495 (in Polish with English abstract).

Miechówka A., Niemyska-Łukaszuk J., Ciarkowska K., 2002. Heavy metals in selected non-forest soils from the Tatra National Park. Chemia i inżynieria ekologiczna 9, 11: 14331438.

Miechówka A., Niemyska-Łukaszuk J., 2004. Content diversity of $\mathrm{Zb}, \mathrm{Pb}$ and $\mathrm{Cd}$ in Lithic Leptosols of the Tatra National Park (Poland). Oecologia Montana 13(1-2): 1-5.

Miechówka A., Piękoś-Mirkowa H., 1998. Oxytropis halleri (Fabaceae) w Tatrach. Fragmenta Floristica et Geobotanica Polonica 5: 9-13 (in Polish with English abstract).

Mišovičová, D., 2003. Geochemical evaluation of the system rock-soil-plant in the selected teritory of the Belianske Tatry Mts. Thesis. Katedra geochémie Prírodovedeckej fakulty Univerzity Komenského, Bratislava: 82 pp. (in Slovak).
Niemyska-Łukaszuk J., 1977a. Charakterystyka próchnicy niektórych leśnych gleb tatrzańskich. Cz. II. Skład frakcyjny połączeń próchnicznych, Roczniki Gleboznawcze - Soil Science Annual 28(1): 170-188 (in Polish with English abstract). Niemyska-Łukaszuk J., 1977b. Charakterystyka próchnicy niektórych leśnych gleb tatrzańskich. Cz. III. Mikromorfologia poziomów butwinowych. Roczniki Gleboznawcze - Soil Science Annual 28(1): 189-203 (in Polish with English abstract).

Niemyska-Łukaszuk J., Miechówka A., 1996. Charakterystyka połączeń próchnicznych rędzin tatrzańskich. [In:] Kotarba A. (ed.) Przyroda Tatrzańskiego Parku Narodowego a człowiek. Tom 1. Nauki o Ziemi. TPN - PTNoZ, Kraków-Zakopane: 179-275 (in Polish with English abstract).

Niemyska-Łukaszuk J., Miechówka A., 2002. Zawartość cynku, ołowiu i kadmu w poziomach powierzchniowych gleb obszarów nieleśnych Tatrzańskiego Parku Narodowego. [In:] A. Kotarba (ed.), Przemiany środowiska przyrodniczego Tatr, Tatrzański Park Narodowy - Polskie Towarzystwo Przyjaciół Nauk o Ziemi, Zakopane: 99-103 (in Polish with English abstract).

Niemyska-Łukaszuk J., Miechówka A., Ciarkowska K., 2000. Rola ektopróchnicy w akumulacji metali ciężkich w glebach obszarów nieleśnych Tatrzańskiego Parku Narodowego. Zesz. Probl. Post. Nauk Roln. 472: 551-558 (in Polish with English abstract).

Oleksynowa K., Skiba S., Kania W., 1977. Wstępne badania nad geochemią rędzin tatrzańskich. Roczniki Gleboznawcze - Soil Science Annual 28(1): 263-275 (in Polish with English abstract).

Passendorfer E., 1996. Geologia. [In:] Mirek Z. (ed.) Przyroda Tatrzańskiego Parku Narodowego. Tatrzański Park Narodowy, Zakopane: 69-96 (in Polish with English abstract).

Pelišek J., 1973. Pôdne pomery Tatranského Národného Parku. Sbornik TANAP 15: 145-180 (in Slovak with English abstract).

Piękoś-Mirkowa H., Mirek Z., Miechówka A., 1996. Endemic vascular plants in the Polish Tatra Mts. - distribution and ecology. Polish Botanical Studies 12: 1-107.

Piękoś-Mirkowa H., Mirek Z., Miechówka A., 2001. Distribution and habitats of Chamaeorchis alpina (L.) Rich. (Orchidaceae) in Poland. Acta Societatis Botanicorum Poloniae 70(2): 107-111.

Skiba S., 1983. Tendencje do strefowości rędzin tatrzańskich na przykładzie stoków Kominiarskiego Wierchu. Roczniki Gleboznawcze - Soil Science Annual 34(4): 101-112 (in Polish with English abstract).

Skiba S., 1985. Rola klimatu i roślinności w genezie gleb na przykładzie gleb górskich z Tatr Polskich i z gór Mongolii. Zeszyty Naukowe AR w Krakowie, ser. Rozprawy Habilitacyjne 99: 72 ss. (in Polish with English abstract).

Skiba S., 1999. Mapa gleb Tatrzańskiego Parku Narodowego. Skala 1:20 000. Uniwersytet Jagielloński-Tatrzański Park Narodowy.

Skiba S., 2002. Mapa gleb Tatrzańskiego Parku Narodowego. [In:] A. Kotarba (ed.), Przemiany środowiska przyrodniczego Tatr, Tatrzański Park Narodowy - Polskie Towarzystwo Przyjaciół Nauk o Ziemi, Zakopane: 21-26 (in Polish with English abstract).

Skiba S., 2006. Pokrywa glebowa strefy wysokogórskiej Karpat i jej zagrożenie. Roczniki Bieszczadzkie 14: 201-214 (in Polish with English abstract). 
Skiba S., Kacprzak A., Szymański W., Musielok Ł., 2011. Walory przyrodnicze górskich gleb rumoszowych. Roczniki Bieszczadzkie 19: 335-348 (in Polish with English abstract).

Skiba S., Koreň M., Drewnik M., Kukla J., 2015. Gleby. [In:] K. Dąbrowska i M. Guzik (eds.). Atlas Tatr - Przyroda nieożywiona. Wydawnictwo TPN, Zakopane, Plansza VI.1.

Strzemski M., 1956. Gleby Tatr Polskich. Roczniki Gleboznawcze - Soil Science Annual 5: 3-71 (in Polish with English abstract).

Systematyka Gleb Polski, 2011. Roczniki Gleboznawcze - Soil Science Annual 62(3): 1-193 (in Polish with English abstract).

Świtoniak M., Kabała C., Charzyński P., 2016. Propozycja anglojęzycznych nazw jednostek Systematyki gleb Polski, Soil Science Annual 67(3): 103-116 (in Polish with English abstract).

Tarábek K., 1956. Zprava o výskume pôd v Belanských Tatrách. Sbornik Prác o Tatranskom Národnom Parku 2: 11-19 (in Slovak).

Varšavová M., Barančok P., Iró S., Medved' J., 1999: Geochemical analysis utilization in the geoecological evaluation of the high-mountain environment of the Belianske Tatry Mts. [In:] Durža O., Rapant S. (eds.), Geochémia. Zborník referátov. GS SR, Vydavatel'stvo Dionýza Štúra, Bratislava: 103-107 (in Slovak).

Wasak K., 2013. Zastosowanie wybranych systemów klasyfikacji do określenia typów materii organicznej w glebach leśnych w Tatrach. Prace Geograficzne 135: 101-119 (in Polish with English abstract).
Wasak K., 2014. Cellulose decomposition rate and features of organic matter in forest soils in the Tatra Mountains. Hruntoznavstvo 15: 70-80.

Wasak K., Drewnik M., 2012a. Properties of humus horizons of soils developed in the lower montane belt in the Tatra Mountains. Polish Journal of Soil Science 45(1): 57-68.

Wasak K., Drewnik M., 2012b. Properties of soil organic matter in abounded pastureland: a case study from the Jaworzynka Valley in the Tatra Mountains, Poland. [In:] Jianming X., Jianjun W., Yan H. (eds.) Functions of Natural Organic Matter in Changing Environment. Springer, Dordrecht, Heidelberg, New York, London (Jointly published with Zhejiang University Press): 203-207.

Wasak K., Drewnik M., 2015. Land use effects on soil organic carbon sequestration in calcareous Leptosols in former pastureland - a case study from the Tatra Mountains (Poland). Solid Earth 6: 1103-1115.

Zanella A., Jabiol B., Ponge J.F., Sartori G., de Waal R., van Delft B., Graefe U., Cools N., Katzensteiner K., Hager H., Englisch M., Brethes A., Broll G., Gobat J.M., Brun J.J., Milbert G., Kolb E, Wolf U., Frizzera L., Galvan P., Kolli R., Baritz R., Kemmers R., Vacca A., Serra G., Banas D., Garlato A., Chersich S., Klimo E., Langohr R., 2011. European Humus Forms Reference Base 56.

Received: April 6, 2018

Accepted: July 10, 2018

Associated editor: t. Uzarowicz

\section{Rędziny Tatr - praca przeglądowa}

Streszczenie: Artykuł zawiera przegląd wiedzy na temat rędzin tatrzańskich występujących w polskiej części Tatr w oparciu o dane literaturowe oraz niepublikowane wyniki i spostrzeżenia autorów pracy, ze szczególnym uwzględnieniem właściwości rędzin wysokogórskich, które na obszarze Polski występują tylko w Tatrach. Omówiony został wpływ czynników glebotwórczych na genezę i przestrzenne zróżnicowanie tych gleb oraz została przedstawiona charakterystyka wyróżnionych jednostek taksonomicznych: rędzin inicjalnych (skalistych i rumoszowych), rędzin próchnicznych (typowych i rumoszowych), rędzin butwinowych (tangelrędzin i amphi-rędzin) i rędzin brunatnych. Zaproponowano też klucz do klasyfikacji rędzin tatrzańskich.

Stowa kluczowe: rędziny, gleby górskie, Tatry, formy próchnicy 